\title{
MONITORING SERUM CREATININE, BLOOD UREA NITROGEN IN PATIENTS BRAIN INJURY WITH MANNITOL THERAPY
}

\author{
Erni A. Sari ${ }^{1}$, Suharjono ${ }^{2}$, Joni Wahyuhadi ${ }^{3}$ \\ ${ }^{1}$ Master Program of Clinical Pharmacy, ${ }^{2}$ Departement of Clinical Pharmacy, Faculty of Pharmacy, Universitas \\ Airlangga, ${ }^{3}$ Department of Neurosurgery, Dr. Soetomo Hospital, Surabaya, Indonesia
}

\section{ABSTRACT}

\begin{abstract}
Increased intracranial pressure is a further effect of brain injury due to structural damage and osmotic and water imbalances (edema). Mannitol works in the proximal tubules and mannitol in the absorption of tubular cells by the mechanism of pinocytosis. The fluid transfer will draw fluid into the intracellular, so that the cell will be switched and broke. This phenomenon is referred to as the phenomenon of "Nephrosis Osmotic", in which mannitol administration may occur as a result of accumulation of drugs in the kidneys due to prolonged exposure to mannitol in the kidney and given dosage. The effects of osmotic diuresis occurring plus the dose and duration of mannitol administration are reported to cause renal function disorders (Scr and BUN). The aim of this study was to analyze changes in serum creatinine and BUN in patients with brain injury from before receiving mannitol therapy and during mannitol treatment. From the results of the study the number of patients who met the inclusion criteria, 32 patients. Serum creatinine, the initial average of $0.85 \pm 0.17 \mathrm{mg} / \mathrm{dl}$ and the last day of the mean SCr $0.74 \pm 0.30 \mathrm{mg} / \mathrm{dl}$. While the mean BUN (Blood Urea Nitrogen) was $11.27 \pm 2.75 \mathrm{mg} / \mathrm{dl}$ and the mean last day was $17.08 \mathrm{mg} / \mathrm{dl} \pm 8.59 \mathrm{mg} / \mathrm{dl}$. From Serum Creatinine and BUN data it can be concluded that there is no significant change.
\end{abstract}

Keywords: Mannitol; serum creatinine; BUN

\section{ABSTRAK}

Peningkatan tekanan intrakranial merupakan efek lanjutan dari cedera otak akibat kerusakan struktur dan ketidakseimbangan osmotik dan air (edema). Manitol bekerja di tubulus proksimal, manitol di absorpsi sel tubulus oleh mekanisme pinositosis. Perpindahan cairan akan menarik cairan ke intrasel, sehingga sel ditubulus akan swelling dan pecah. Kejadian ini disebut sebagai fenomena "Nephrosis Osmotic", dimana pada pemberiaan manitol dapat terjadi akibat dari akumulasi obat diginjal karena lama paparan manitol pada ginjal dan dosis yang diberikan. Efek diuresis osmotik yang terjadi ditambah dengan dosis dan lama pemberiaan manitol dilaporkan menyebabkan gangguan funsi ginjal (Scr dan BUN). Tujuan dari penelitian ini adalah mengetahui perubahan Serum kreatinin dan BUN pada pasien cedera otak dari sebelum mendapatkan terapi manitol dan selama pemberiaan manitol. Dari hasil penelitian jumlah pasien yang memenuhi kriteria inklusi, 32 pasien. Serum Kreatinin, rerata awal $0,85 \pm 0,17 \mathrm{mg} / \mathrm{dl}$ dan hari terakhir pemberian rerata $\mathrm{SCr} 0,74 \pm 0,30 \mathrm{mg} / \mathrm{dl}$. Sedangkan rerata BUN (Blood Urea Nitrogen) 11,27 $\pm 2,75 \mathrm{mg} / \mathrm{dl}$ dan rerata hari terakhir 17,08 $\mathrm{mg} / \mathrm{dl} \pm 8,59 \mathrm{mg} / \mathrm{dl}$. Dari data Serum Kreatinin dan BUN dapat disimpulkan bahwa tidak ada perubahan bermakna.

Kata kunci: Manitol; serum kreatinin; BUN

Correspondence: Suharjono, Departement of Clinical Pharmacy, Faculty of Pharmacy, Universitas Airlangga, Surabaya, Indonesia. Phone: 08121733877. E-mail: shj_ms_id@yahoo.com

pISSN:2355-8393 • eISSN: 2599-056x • doi: http://dx.doi.org/10.20473/fmi.v56i4.23406

- Fol Med Indones. 2020;56:254-260 • Received 5 Nov $2018 \bullet$ Accepted 16 May 2019

- Open access under CC-BY-NC-SA license • Available at https://e-journal.unair.ac.id/FMI/

\section{INTRODUCTION}

Increased intracranial pressure is a further effect of brain injury due to structural damage and an osmotic and water imbalance called Edema (Werner \& Engelhard 2007). Increased intracranial pressure will cause a decrease in cerebral blood flow resulting in tissue ischemia. This ischemic state will produce vasodilation response through autoregulation mechanism to restore cerebral blood flow. Although vasodilation can increase blood volume in the brain but this will increase intracranial pressure so that it will decrease brain blood perfusion which will eventually lead to further ischemia (Patro \& Mohanty 2009).

Hyperosmolar therapy is a principal intervention given for the management of cerebral edema and an increase in intracranial pressure that appears after head trauma. 
Mannitol is the most commonly used osmotic diuretic. Mannitol has an immediate effect which results from its mechanism of action as a plasma expander and in its ability to improve rheology in order to reduce hematocrit. Effects that result from mannitol treatment include: The dehydration effect of the brain by reducing the accumulation of fluid in the interstitial space so that the volume of brain tissue is relatively reduced and the rheological effect, which improves microcirculation thus improves the penetration ability of red blood cells which in turn will guarantee tissue oxygenation and maintain the pump $\mathrm{Na}$ (Patro \& Mohanty 2009). Mannitol may be administered as a bolus of $0.5-1 \mathrm{~g} / \mathrm{kg}$ or repeated doses, e.g., (4-6) x 100 cc mannitol 20\% in 24 hours, mannitol gradually discontinued (Helmy et al 2007, Darmadipura et al 2010).

Mannitol has the effect of diuresis by reducing the buildup of fluid in the interstitial space so that the volume of brain tissue is relatively reduced and creates an osmotic gradient that draws fluid from brain tissue that is edematous to the circulation (Patro \& Mohanty 2009). Mannitol works in the proximal tubule, in the absorption of tubular cells by the mechanism of pinocytosis. The fluid transfer will draw fluid into the intracellular, so that the cell will be switched and broke. This phenomenon is referred to as the phenomenon of "Nephrosis Osmotic", in which mannitol administration may occur as a result of accumulation of renal medicines due to prolonged exposure of mannitol to the kidney and given dose (Shawkat \& Westwood 2012, Fang et al 2010). The effects of osmotic diuresis occurring plus the dose and duration of mannitol administration are reported to cause impaired renal function of Scr and BUN.

Mannitol excretion can cause electrolyte and fluid balance disturbances, recurrent cerebral edema, osmolal gap, hypersensitivity reactions. Mannitol as osmotic diuretics, filtrated in glomerolus and almost or not in reabsorption in proximal tubules. Where diuresis effects occur and the osmotic pressure tends to increase, it will bind the osmotic water and maintain it in the tubular lumen. High osmolarity $>320 \mathrm{mmol} / \mathrm{L}$ is the cause of renal impairment (Rose \& Post 2007). The study was conducted by looking at data of patients diagnosed with brain injury with increased intracranial pressure and received mannitol therapy at Dr. Soetomo Hospital, Surabaya.

\section{MATERIALS AND METHODS}

This study used restropective data from January 1, 2014 to 31st July 2016. Patients who met the inclusion criteria were patients receiving mannitol therapy starting from loading dose $200 \mathrm{ml}$, followed by tapering dose starting from a dose of $6 \mathrm{x} 100 \mathrm{ml}$ to $100 \mathrm{ml}$ last day. This research has obtained the approval of ethical conduct by the Dr. Soetomo Hospital Ethics Committee.

\section{RESULTS}

From the results of the study the number of patients who met the inclusion criteria, 32 patients. Serum creatinine, the initial average of $0.85 \pm 0.17 \mathrm{mg} / \mathrm{dl}$ and the last day of the mean SCr $0.74 \pm 0.30 \mathrm{mg} / \mathrm{dl}$. While the mean BUN (Blood Urea Nitrogen) was $11.27 \pm 2.75 \mathrm{mg} / \mathrm{dl}$ and the mean last day was $17.08 \mathrm{mg} / \mathrm{dl} \pm 8.59 \mathrm{mg} / \mathrm{dl}$. From serum creatinine and BUN data it can be concluded that there is a significant change.

\section{DISCUSSION}

Mannitol was given intravenously, and largely distributed in extracellular. Mannitol filtrated at the glomerulus and excreted in unchangeable shapes in urine. The initial research stated that after a single dose of mannitol was administered intravenously, after 15 minutes, it got excreted 50 percent and after 24 hours, 90 percent of it recovered in urine. The next research conducted to observed mannitol pharmacokinetic to humans, where a single dose of mannitol $0,5-0,71 \mathrm{~kg} \mathrm{t}$ $1 / 2$ occurred between 39 to 103 minutes with average $t$ $1 / 2$ mannitol 71 minutes. In the same research mentioned when the mannitol IV speed reached the maximum excretion speed in kidney, the progressive accumulation mannitol in the extracellular fluid was produced. The outcome of mannitol accumulation caused cellular dehydration, which caused the reduction of brain edema (Dorman et al 1990).

Mannitol was an osmotic diuretic which freely filtrated by the glomerulus, practically without reabsorption at tubules, so the water absorption could be blocked. Mannitol didn't guarantee to decrease water content inside injured brain cells, mannitol reduced water content in uninjured brain cells that could give more space for swollen injured brain cells. The fast administration by intravenous bolus was more effective than slow intravenous in reducing intracranial pressure (Hinson et al 2011).

The most common brain injury was severe brain injury in all of the monitoring studies conducted (Table 1). Where brain injury patients were classified according to GCS values ranged from 3 to 8 . The age group with the highest brain injury was the age group of 16 to 39 years, although patients in the 40-60 age group showed a difference of 1 patient (Table 1). 
Table 1. Characteristics of patients who received mannitol

\begin{tabular}{|c|c|c|c|c|c|}
\hline Patient & Age & Sex & $\begin{array}{l}\text { Osmolarity } \\
(\mathrm{mmol} / \mathrm{L})\end{array}$ & Injury Type & $\begin{array}{l}\text { Blood Presure } \\
(\mathrm{mmHg})\end{array}$ \\
\hline 1 & 28 & $\mathrm{~F}$ & 236.33 & severe brain injury & $110 / 70$ \\
\hline 2 & 19 & M & 269.07 & severe brain injury & $124 / 76$ \\
\hline 3 & 54 & M & 296.22 & severe brain injury & $150 / 90$ \\
\hline 4 & 50 & $\mathrm{~F}$ & 298.67 & severe brain injury & $160 / 63$ \\
\hline 5 & 40 & $\mathrm{~F}$ & 294.17 & severe brain injury & $120 / 80$ \\
\hline 6 & 60 & M & 306.81 & severe brain injury & $113 / 76$ \\
\hline 7 & 33 & M & 316.50 & severe brain injury & $144 / 60$ \\
\hline 8 & 25 & M & 300.12 & severe brain injury & $130 / 70$ \\
\hline 9 & 15 & M & 304.27 & severe brain injury & $125 / 75$ \\
\hline 10 & 60 & M & 296.07 & severe brain injury & $150 / 110$ \\
\hline 11 & 55 & M & 292.72 & severe brain injury & $122 / 64$ \\
\hline 12 & 19 & $\mathrm{~F}$ & 253.19 & $\begin{array}{l}\text { severe brain injury } \\
\text { moderate brain }\end{array}$ & $140 / 70$ \\
\hline 13 & 21 & M & 302.82 & $\begin{array}{c}\text { injury } \\
\text { moderate brain }\end{array}$ & $120 / 80$ \\
\hline 14 & 75 & M & 313.59 & $\begin{array}{l}\text { injury } \\
\text { moderate brain }\end{array}$ & $120 / 80$ \\
\hline 15 & 35 & M & 308.25 & $\begin{array}{c}\text { injury } \\
\text { moderate brain }\end{array}$ & $120 / 80$ \\
\hline 16 & 70 & $\mathrm{~F}$ & 290.02 & $\begin{array}{l}\text { injury } \\
\text { moderate brain }\end{array}$ & $155 / 73$ \\
\hline 17 & 30 & M & 293.52 & $\begin{array}{l}\text { injury } \\
\text { moderate brain }\end{array}$ & $137 / 86$ \\
\hline 18 & 50 & $\mathrm{~F}$ & 299.58 & $\begin{array}{c}\text { injury } \\
\text { moderate brain }\end{array}$ & $128 / 73$ \\
\hline 19 & 55 & $\mathrm{~F}$ & 288.49 & $\begin{array}{c}\text { injury } \\
\text { moderate brain }\end{array}$ & $180 / 77$ \\
\hline 20 & 48 & M & 292.19 & $\begin{array}{l}\text { injury } \\
\text { moderate brain }\end{array}$ & $110 / 70$ \\
\hline 21 & 20 & M & 300.90 & injury & $120 / 80$ \\
\hline 22 & 25 & M & 297.97 & $\begin{array}{l}\text { severe brain injury } \\
\text { moderate brain }\end{array}$ & $107 / 62$ \\
\hline 23 & 26 & M & 303.82 & injury & $98 / 70$ \\
\hline 24 & 57 & M & 299.96 & severe brain injury & $120 / 84$ \\
\hline 25 & 72 & M & 287.97 & severe brain injury & $140 / 80$ \\
\hline 26 & 47 & $\mathrm{~F}$ & 298.48 & severe brain injury & $127 / 77$ \\
\hline 27 & 18 & $\mathrm{~F}$ & 341.99 & severe brain injury & $154 / 89$ \\
\hline 28 & 60 & M & 294.43 & severe brain injury & $140 / 90$ \\
\hline 29 & 53 & M & 304.96 & severe brain injury & $160 / 90$ \\
\hline 30 & 58 & M & 286.36 & severe brain injury & $112 / 70$ \\
\hline 31 & 24 & M & 309.01 & $\begin{array}{l}\text { severe brain injury } \\
\text { moderate brain }\end{array}$ & $130 / 71$ \\
\hline 32 & 26 & M & 297.20 & injury & $90 / 60$ \\
\hline
\end{tabular}




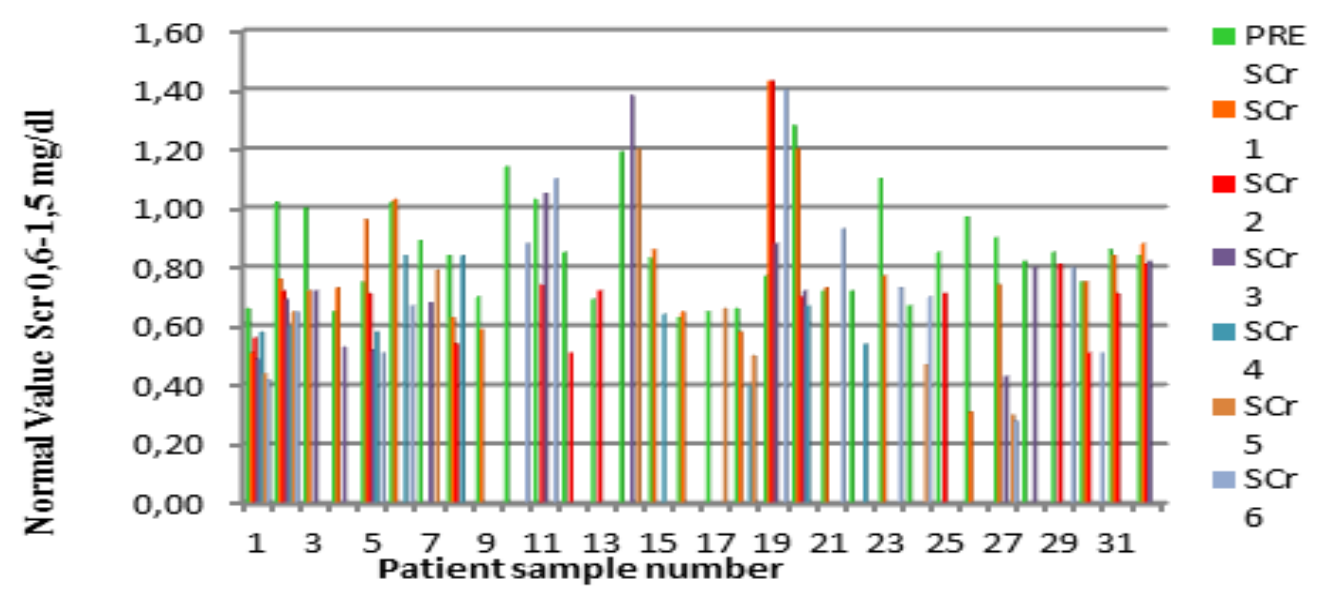

Fig. 1. Distribution of serum creatinine before and during mannitol was administered.

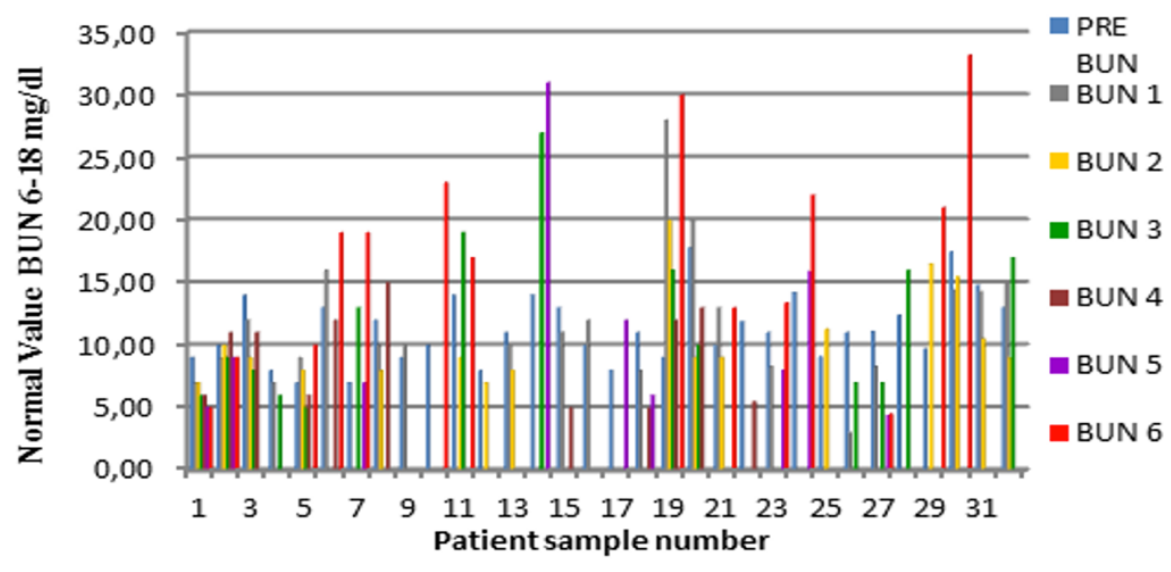

Fig. 2. Distribution of BUN before and during mannitol was administered.

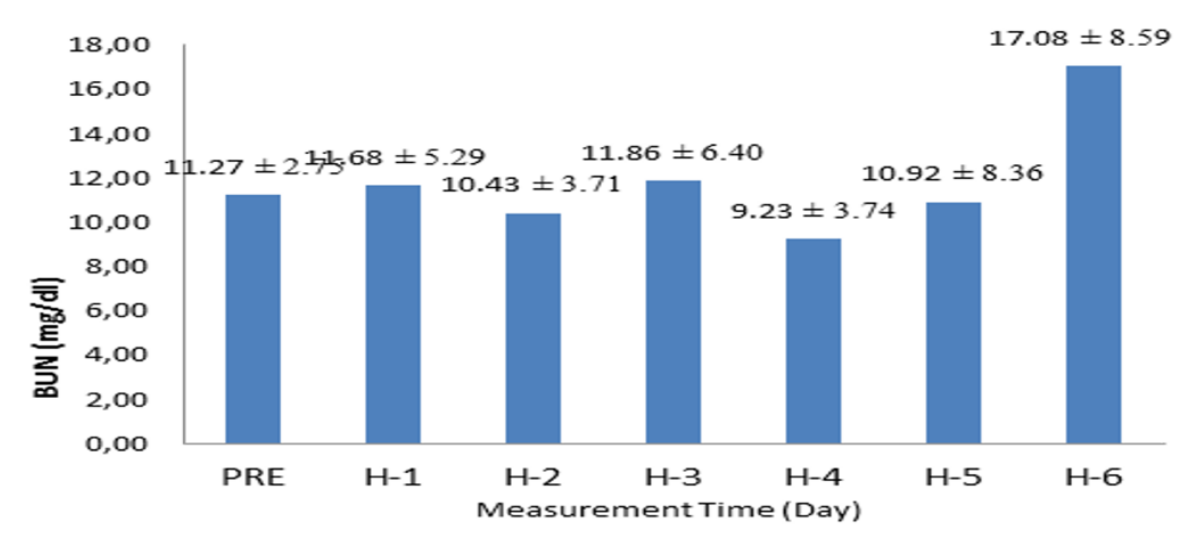

Fig. 3. The average change of serum creatinine before and during mannitol was administered. 


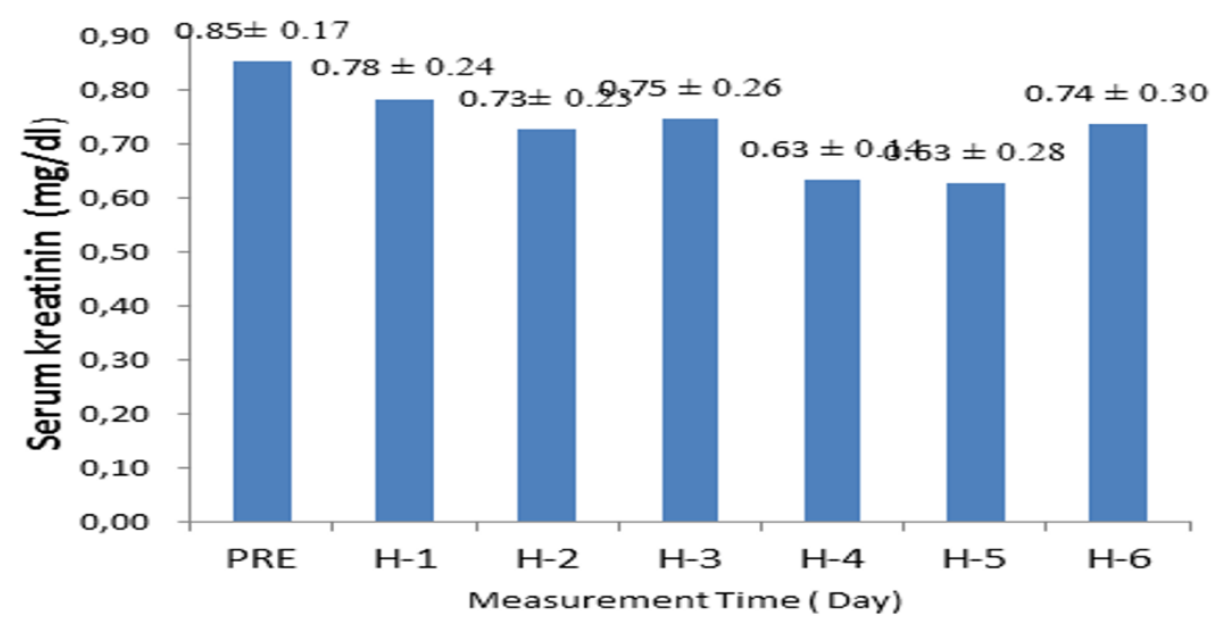

Fig. 4. The average change of BUN before and during mannitol was administered.

Data on both the classification of brain injury and age group is one of the features recommended by the Brain Trauma Foundation for monitoring of patients' intracranial pressure (Anonim 2016).

Some researchers reported that the risk of acute renal failure due to increased age, so the kidneys are reduced due to acute stress. (Pérez-Pérez et al 2002, Li et al 2015) mentioned that patients with old age have a higher risk of acute renal failure. Other studies have also reported that age is one factor that can increase the occurrence of acute renal failure in patients receiving mannitol (Kim et al 2014).

Osmolarity and systolic blood pressure are important things to consider if the patient is receiving mannitol therapy. All samples received mannitol starting from LD $200 \mathrm{ml}$, then received mannitol tapering dose starting from $6 \times 100 \mathrm{ml}$, where mannitol proliferation was used as a therapy because the patient had an increased intracranial pressure (Helmy A et al 2007, Darmadipura et al 2010). On serum creatinine monitoring, an initial examination of patients involving osmolarity and systolic blood pressure of the patient, where the osmolarity score should not exceed 320 $\mathrm{mmol} / \mathrm{L}$ and the patient's systolic blood pressure should not be less than $90 \mathrm{mmHg}$. From Table 1 one patient with a value of 320.44 osmolarity was found to be the upper limit of the normal osmolarity value, the reason why mannitol remained in was that the patient had a history of Diabetes Mellitus so as to normalize the blood sugar value is difficult, so that mannitol administration was given and checking blood sugar as it continues to be monitored. Table 1 also shows an osmolarity value that exceeds the osmolarity value of patient no.10 with a history of Diabetes Mellitus whereas patient No.23 which affects the osmolarity value so that $321.75 \mathrm{mmol} / \mathrm{L}$ is the BUN value of 22 $\mathrm{mg} / \mathrm{dl}$ above normal value, no history kidney disease, and patient age 50 years.

Creatinine was one of substance originated from organ metabolism which through glomerulus filtration process, while tubules secretion was very minimal so we could abandon, therefore creatinine was very useful for glomerulus evaluation.

The increasing of creatinine plasma $1-2 \mathrm{mg} / \mathrm{dl}$ from normal based showed GFR declined $\rightarrow \pm 50 \%$. A research analysed mannitol as the causes of acute kidney injury, where the sample was divided into 2 groups, the ones who have a kidney problem and the ones who didn't have a kidney problem. On the first and second day after mannitol administered, samples with the kidney problem and didn't have kidney problem experienced increasing serum creatinine (Fang L et al. 2010). Other research investigated 158 patient with $\mathrm{ICH}$ who received mannitol, $10.5 \%$ of them encountered acute kidney injury. (Min Young Kim et al. 2014). Several researches reported incidents of acute kidney injury on brain injury patients and subarachnoid haemorrhage aneurysm with percentages for each of them were $76 \%$, $23,1 \%, 23 \%$. There were several researchers reported that the risk of acute kidney injury due to increasing age so the kidney reduced by acute stress. The same research reported that age was one of the factors that could increase the risk of acute kidney injury in patients who received mannitol administration (Dziedzic et al 2003).

Other research stated that there was an increasing intracranial with mannitol dosage $200 \mathrm{~g}$ /day and the 
total dosage was $1100 \mathrm{~g}$. The daily maximum dosage that received in this research was $160 \mathrm{~g}$ on the first day and the total dosage that received was $480 \mathrm{~g}$. This dosage was lower than dosage that mentioned in other research, so it wasn't strong enough to cause acute kidney injury (Dickenmann et al 2008).

Dorman et al (1990) concluded that the speed of mannitol IV that could cause acute kidney injury where the daily dosage was $189 \pm 64 \mathrm{~g}$ and the total dosage was $626 \pm 270 \mathrm{~g}$ in mannitol administration $3.5 \pm 1.5$ days (Dorman et al 1990). Other research noted that 4 acute kidney injury patients after receiving mannitol IV with IV speed $0.25 \mathrm{~g} / \mathrm{kg} /$ hour. The explanation above described that $\mathrm{t} 1 / 2$ mannitol on normal kidney function was 70 minute, and mannitol was repeated after 4-6 hours with assumptions the majority of dosage had been secreted (Pérez-Pérez et al 2002). When the IV speed exceeded kidney excretion speed, mannitol could accumulate in extracellular space and could cause high local osmolarity in the kidney which potentially produced vasoconstriction in kidney and GFR declining. A report said the patient with kidney problem will be recovered after mannitol stopped and after received kidney replacement therapy. However, despite kidney problem associated with bad consequences for either short or long term, the acute kidney problem still happened even though got covered.

Serum creatinine in the sample based on Fig 1 and Figure 3 Mean Serum creatinine did not exceed the normal value of $0.6-1.5 \mathrm{mg} / \mathrm{dl}$. However when looking at Figure 1, the patient 14 initial $\mathrm{SCr}$ values before admission was $1.19 \mathrm{mg} / \mathrm{dl}$ on the third day of administration to $1.38 \mathrm{mg} / \mathrm{dl}$ where the increase was $0.19 \mathrm{mg} / \mathrm{dl}$. Patients 17 initial Scr value was $0.77 \mathrm{mg} / \mathrm{dl}$ on the first day after mannitol delivery increased to 1.43 $\mathrm{mg} / \mathrm{dl}$, with an increase of $0.66 \mathrm{mg} / \mathrm{dl}$ then stabilized on day one, and decreased on day two. Based on previous studies the increase in serum creatinine increased after loading dose loading and during the first day of good mannitol administration and continued to decline (Moore et al 2010). In one method to see if the patient had acute renal failure is to look at the definition of KDQI as one of the references, where patients can be said to experience acute state renal failure if there is an increase of $0.3 \mathrm{mg} / \mathrm{dl}$ of serum creatinine. Based on Table 1 of 32 samples there was an increase of 0.66 $\mathrm{mg} / \mathrm{dl}$ in patient number 19 , an increase occurring on the first day after the patient received mannitol on loading dose and on the first day after delivery, at a dose administered on the first day of $800 \mathrm{ml}$, from loading dose $200 \mathrm{ml}$ and initial dose of $600 \mathrm{ml}$. Then on the second day of the $500 \mathrm{ml}$ dose, Dorman et al (1990) mention that when the infusion rate exceeds the rate of renal excretion, mannitol can be accumulated in the extracellular space and can lead to high local osmolarity in the kidney potentially producing vasoconstriction in the kidney and decreased GFR, Serum creatinine has been increased because of the dose given. (Dorman et al 1990).

Urea is the largest nitrogen product secreted by the kidneys derived from diets and endogenous proteins that have been filtered by the glomerulus and partially reabsorbed by the tubules. Urea gets more reabsorbed in a state where urine is slow or disturbed (dehydration). Nitrite urea number in this study one of them is connected with osmolarity changes that occur. Based on Figure 2 the increase in BUN is shown in Fig. 2, i.e., in patients $6,7,10,14,19,20,24,29$ and 30 . In the calculation of osmolarity, in the 9 patients based on Table 1 Patient No. 6, 7, 10, 14, 24, 29, and 30 increase of BUN on day 6 , patients 19 and 20 on day 1 . Osmolarities above 300 $\mathrm{mmol} / \mathrm{L}$ are patients of 6.7 and 15 , which can be concluded that increased osmolarity leads to BUN removal, in addition patients no.14 also have a history of diabetes mellitus and Hypertension so that it also affects the value of osmolarity increased. The workings of Osmotic Diuretics from Mannitol is to increase plasma osmolality and to draw normal fluid from within the low osmolary to the high osmolar intravascular cells, to reduce cerebral edema. In general, high osmolarity is used to decrease intracranial pressure, but an osmolarity exceeding $320 \mathrm{mmol} / \mathrm{L}$ may cause the effect of increased diuresis, thus affecting electrolyte and fluid changes, which is one of the factors that can increase BUN.

The workings of Osmotic Diuretics from Mannitol in the kidney system work to limit water reabsorption especially in the segment where nephrons are highly permeable to water, i.e., proximal tubules and descending henle ansa. The presence of a substance that cannot be reabsorbed by water due to an osmotic pressure that is against balance. Mannitol is an ion transport inhibitor which lowers the reabsorption of $\mathrm{Na}$ + and other ions such as $\mathrm{Cl}+$ and enters the urine in greater quantities than in normal conditions with water, which passively transport to maintain the osmotic balance. The osmotic changes which in the tubules become increased due to more sodium in the urine, and bind more water in the renal tubules. And urine production becomes more numerous. Thus diuretics increase the volume of urine and often alter its $\mathrm{pH}$ and ionic composition in urine and blood. As a result, the urine volume increases with the excretion of mannitol. (Bhat et al 2008, Manninen et al 1987).

Research on the effect of mannitol on the kidneys can be seen from the serum creatinine value, but other studies can be done by looking at electrolytes because 
Mannitol has the effect of increasing the excretion of sodium, water, potassium and chloride, as well as other electrololites. Mannitol works in the proximal tubule, mannitol in the absorption of tubular cells by the mechanism of pinocytosis. The fluid transfer will draw fluid into the intracellular, so that the cell will be switched and broke. This phenomenon is called the phenomenon of "Nephrosis Osmotic", where in mannitol can occur as a result of the accumulation of renal medicine due to prolonged exposure.

\section{CONCLUSION}

Based on a retrospective study of Serum creatinine and BUN changes with $20 \%$ mannitol loading with $200 \mathrm{ml}$ loading dose followed by tapering dose ranging from 6 $\mathrm{x} 100 \mathrm{ml}$ in brain injury patients performed in Dr. Soetomo Hospital, Surabaya can be concluded that there is no significant change of Creatinine Serum and BUN between time measurements from before and during mannitol administration.

\section{REFERENCES}

Anonim (2016). The brain trauma foundation. the american association of neurological surgeons. the joint section on neurotrauma and critical care. Indications for intracranial pressure monitoring. $\mathrm{J}$ Neurotrauma, $p$ 49-56; 132-144

Bhat R, Hudson K, Sabzevasi T (2008). An evidence based approach to severe traumatic brain injury. EBMedicine 10, 12

Darmadipura PH, Kasan U, Bajamal HA, Turchan A, Parenrengi A \& Wahyuhadi, J (2010). Pedoman diagnosis dan terapi bag/SMF ilmu bedah saraf. Surabaya, Rumah Sakit Umum Dokter Soetomo, $\mathrm{p}$ 2-3

Dickenmann M, Oettl T, Mihatsch MJ (2008). Osmotic nephrosis: acute kidney injury with accumulation of proximaltubular lysosomes due to administration of exogenous solutes. American Journal Nephrology $51,491-503$

Dorman, et al (1990). Mannitol induced acute renal failure. Journal Medicine 69
Dziedzic T, Szczudlik A, Klimkowicz A, Rog TM, Slowik A (2003). Is mannitol safe for patients with intracerebral hemorrhages? Renal considerations. Clin Neurol Neurosurg 105, 87-9

Fang L, You H, Chen B, Xu Z, Gao L, Liu J, et al (2010). Mannitol is an independent risk factor of acute kidney injury after cerebral trauma: a casecontrol study. Journal Renal Failure, 673-679.

Helmy A, Vizcaychipi M, Gupta AK (2009). Traumatic brain injury: intensive care management. BrJ Anaesth 99, 32-42

Hinson H, Stein D, Sheth NK (2011). Hypertonic Saline and Mannitol therapy in critical care neurology.J Intensive Care Med 28, 3-11

Li M, Chen T, Chen SD, Cai J, Hu YH (2015). Comparison of equimolar doses of mannitol and hypertonic saline for the treatment of elevated intracranial pressure after traumatic brain injury: a systematic review and meta-analysis. Medicine (Baltimore) 94, e 736

Manninen PH, Lam AM, Gelb AW, Brown SC (1987). The effect of high doses mannitol on serum and urine electrolytes and osmolarity in neurosurgical patients. Canadan Journal Anaestheology, 442-6

Kim MY, et al (2014). Increased risk of acute kidney injury associated with higher infusion rate of mannitol in patients with intracranial hemorrhage. Journal Neurosurgery, 1-9

Moore ME, Bellomo R, Nichol A, Harley N, MacIsaac C, Cooper DJ (2010). The incidence of acute kidney injury in patient with traumatic brain injury. Journal Renal Failure, 1060-1065

Patro A, Mohanty S (2009). Pathophysiology and treatment of traumatic brain edema. Indian Journal Neurotama 6, 11-16

Pérez-Pérez AJ, Pazos B, Sobrado J, Gonzalez L, Gándara A (2002). Acute renal failure following massive mannitol infusion. American Journal Nephrology 22, 573

Rose BD, Post TW (2007). Mechanism of actions diuretic.

Shawkat H, Westwood MM, (2012). Mannitol: a review of its clinical uses. British Journal of Anesteshia, 1-4

Werner \& Engelhard (2007). Pathophysiology of traumatic brain injury. British Journal of Anaesthesia 99, 4-9 